\title{
PROBLEMS OF THE DEVELOPMENT OF TRUST MANAGEMENT IN THE CONDITIONS OF THE MODERN GLOBAL FINANCIAL MARKET \\ ๑2021 PERMINOV S. B.
}

UDC 336.714

JEL: D53; E22; 016

\section{Perminov S. B. Problems of the Development of Trust Management in the Conditions of the Modern Global Financial Market}

The article examines the key problems of the development of the trust management market at the present stage of the formation of the global market. All problems are identified within the framework of the main trends in the development of the financial market, which is associated with the complication of its subject structure, changes in the structure of instruments. In addition, the market is actively expanding due to the introduction of intermediaries and social media as specific market players. The active digitalization of economic activity leads to the formation of new industries, including the need to form a cyber security system. New rules for the functioning of the trust management market require the development of appropriate regulatory support for the functioning of the market and the formation of global value chains. A problematic issue is also the awareness of new clients with trust management services, the rules of the market functioning. It is worth considering the processes of global offshorization, which determines the key directions of normative regulation both in the global market and its regional adaptation. In this regard, the paper discusses the features of the development of regulatory support for the functioning of the financial market in general, as well as the market of trust operations in particular in modern conditions, with examples of the implementation of this conception in certain highly developed countries (United States of America, Great Britain, etc.) taking into account the requirements of international organizations to ensure and regulate these markets in order to counter money laundering, tax evasion, and concealment of the tax base. In addition, the article proposes some options for minimizing the negative consequences of key problems in the development of the trust management market or minimizing the associated risks.

Keywords: trust management, trust management market, trust, banking activity.

DOI: https://doi.org/10.32983/2222-4459-2021-9-196-201

Fig.: 1. Bibl.: 18.

Perminov Stanislav B. - Postgraduate Student, ISMA University of Applied Sciences (Bldg 7, 1 Lomonosova Str., Riga, LV-1019, Latvia) E-mail: Psb70@protonmail.com

УДК 336.714

JEL: D53; E22; 016

\section{Пермінов С. Б. Проблеми розвитку довірчого управління в умовах сучасного глобального фінансового ринку}

у статті розглядаються ключові проблеми розвитку ринку довірчого управління на сучасному етапі становлення глобального ринку. Усі проблеми визначено в рамках основних трендів розвитку фінансового ринку, що пов'язане з ускладненням його суб'єктної структури та зміною структури інструментів. Крім того, активне розширення ринку відбувається і за рахунок упровадження посередників і соціальних медіа як специфічних гравців ринку. Активна диджиталізація економічної діяльності приводить до формування нових галузей діяльності, у тому числі й до необхідності формування системи кібербезпеки. Нові правила функціонування ринку довірчого управління вимагають розробки відповідного нормативного забезпечення функціонування ринку та формування глобальних ланцюжків створення вартості. Проблемним питанням $\epsilon$ також і поінформованість нових клієнтів з послугами довірчого управління, правилами функціонування ринку. Варто враховувати і процеси глобальної офшоризації, яка визначає ключові напрямки нормативного регулювання як на глобальному ринку, так і його регіональну адаптацію. У зв'язку з цим у роботі розглянуто особливості напрацювання нормативно-регуляторного забезпечення функціонування фінансового ринку в цілому, а також ринку довірчих операцій зокрема в сучасних умовах, із прикладами реалізації даної концепції в окремих високорозвинених країнах (Сполучені Штати Америки, Велика Британія та ін.), з урахуванням вимог міжнародних організацій до забезпечення та регулювання даних ринків з метою протистояння відмиванню грошей, ухилянню від сплати податків, прихованню бази оподатковування. Крім того, у статті запропоновано деякі варіанти мінімізації негативних наслідків ключових проблем розвитку ринку довірчого управління або мінімізації пов'язаних із цим ризиків.

Ключові слова: довірче управління, ринок довірчого управління, траст, банківська діяльність.

Рис.: 1. Бібл.: 18.

Пермінов Станіслав Борисович - аспірант Вищої школа менеджменту інформаційних систем (вул. Ломоносова 1, корпус 7, Рuгa, LV-1019, Латвія) E-mail: Psb70@protonmail.com

$\mathrm{T}$ he development of the trust services market is taking place in the context of the development of new rules for regulating the financial market as a whole and the formation of a new market format. It is associated with global restructuring and reorganization of the market, the emergence of new instruments and, accordingly, the need to comprehend new behavior strategies for banks in the financial services market. In these conditions, both new challenges for the trust management (TM) industry and new opportunities are being formed.
The formation of the trust management market, and trust relations, in particular, has become the object of research in a significant number of scientific works. For example, general issues of asset management are analyzed in the works by I. Smirnov [15], A. Vorotilov [8], A. Kovalevich [11], F. Ripol-Saragossi [14], S. Budylgin [7] and others. We find certain issues of managing specific assets in the works by A. Asaul [5], M. Moroz [13], A. Genkin [9] and other scientists. Legal regulation of asset management processes is the basis of research 
by Fedulova D. [16], Mazaeva A. [12], Zweigert K. [17], Dozortsev V. [10]. However, special attention should be paid to the issues of determining the key problems of the development of the trust management market at the present stage.

Taking into account all the abovementioned, the purpose of the article is to identify the key problems in the development of the trust management market at the present development stage of the global economy.

$\mathrm{T}$ The development of the trust management market is accompanied by the presence of a significant number of problems and asymmetries, which are a natural consequence of the development of new markets. Based on the generalization of modern international practice of trust management, the key groups of problems of the trust management market at the present stage of its development have been systematized and identified (Fig. 1).

Trust management services can be classified as "clean" banking services. However, since they are actively developing and transforming due to objective economic circumstances, a more in-depth analysis and determination of their place in the structure of the functional activities of banks or the development of the financial market as a whole is required [6]. Trust management has undeniable advantages, since it creates opportunities for the distribution of risks between all participants in the trust relationship. So, the key risks are associated with the object of placement, trustee, client, bank, company, etc. Nevertheless, the development of trust management faces significant problems and barriers in the global financial market.

Some scholars consider the following as key obstacles to the development of the trust services market:

1) the unwillingness of the banking structure to systematically provide trust management services;

2) unwillingness of clients to place assets under management, which may be determined by the availability of new investment instruments;

3) the complexity of forecasting the development of the financial market, in general and the trust management market, in particular;

4) the complexity of trust management tools for understanding and lack of the possibility to clearly predict the development of the securities market;

5) the complexity of the procedure of providing trust management services in banking practice [9].

Significant problems in banking are such as growing costs associated with the growth of assets and their maintenance costs, and the necessity to respond to new regulations and comply with all the requirements stated in them. In addition, the increase in costs is associated with the need to expand the network of the company's representative offices in connection with the formation of a global market for trust management services. Of particular interest may be emerging markets, which include the markets of South America, Africa, Asia and the Middle East [2]. In addition, the transparency of commissions or other remuneration for managers remains a topical issue. On the one hand, this interest is influenced by investors and the formation of the global market, and on the other hand, the pricing policy is acquiring regional features even for global firms, thus helping companies to meet the requirements of clients (especially large or institutional ones, such as pension funds, insurance funds, endowments, government funds, etc.). These clients primarily require a fairly wide investment portfolio and alternative products with varying degrees of risk.

In addition, market globalization causes the necessity to develop new development strategies; however, significant differences in the development of markets or their regional characteristics prompt the development of management strategies for each investor, individually. A new feature of the market is the spread of innovative technologies and social networks and platforms as tools for market development or attracting consumers. Accordingly, the costs of IT and targeted trust representation will grow. In general, investments in information technologies are expected to exceed other investments.

$\mathrm{F}$ urthermore, the structure of the client base of trust management services is changing. Young clients, just beginning to form their savings, are entering the trust management market. However, such clients provide different requirements for companies and have a sufficiently high level of trust in social media, causing a reorientation of the market towards new tools. It is becoming possible to form banking alliances with social media to create a compelling proposition, such as combining banks with social networks (e. g., Facebook or Twitter), which could provide distribution services. Paypal may also be included in such banking unions, since a wide range of consumers trust large technology companies with a worldwide and solid reputation. The development of this area is already taking shape. For example, Alipay acquired Tianhong Asset in 2013, and as a result, clients of the payment company could use trust services and expand their investment portfolios. The enlargement of companies and the formation of banking unions, in turn, can lead to cost reduction of trust management services [1].

Separation of processing, maintenance and storage of assets is another feature of the modern development of the trust management market. In this case, the formation of such value chains is possible, which would include providers, industry enterprises, utilities, etc.

A separate branch of storing statistical data, which is created in the process of asset management, is also being formed. The formation of a global market, providing customer service all over the world, causes the necessity to develop a single Data Center that could serve the flows of information and statistical data, which would simplify customer service, but could lead to unfair competition in the trust management market. In general, the division between the global and regional markets is leveled. 


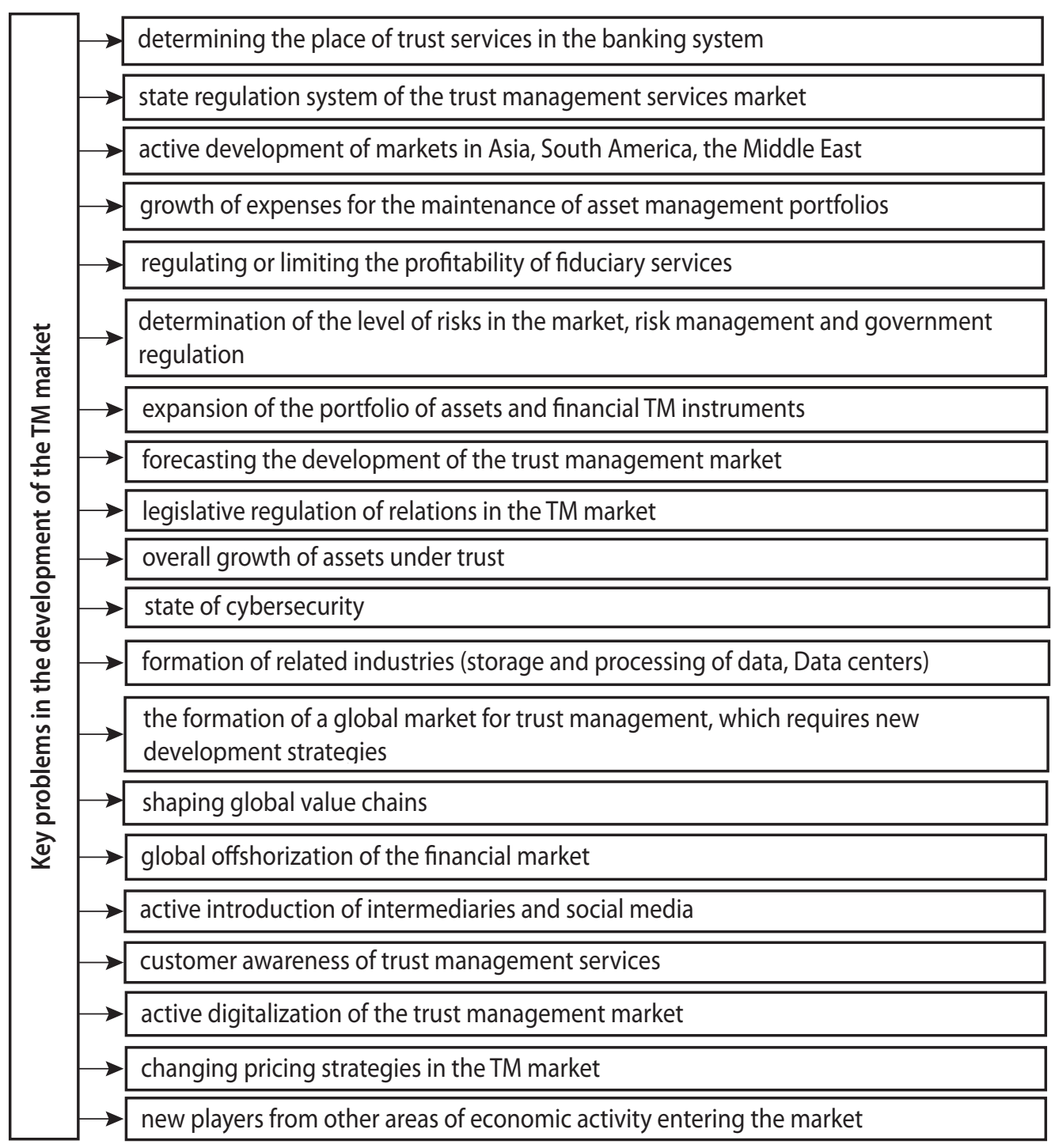

Fig. 1. Systematization of the development problems of the trust management market

Source: systematized by the author.

The formation of a single Data Center will help managers implement investment capital management both globally and regionally. In turn, this can automate some processes and facilitate customer access and awareness regarding the movement of money in accounts and investment instruments. Such Data Centers can contain information not only about traditional accounts, but also accounts in cryptocurrency, digital keys, identity cards, etc., collecting information from various sources and consolidating it into a single record. However, lack of banking secrecy can become a real problem, creating the flip side of the formation of such Data Centers. In addition, cybersecurity, protection of information about the clients and their accounts can become an important element in this case.

In turn, this will require managers to better inform their clients as for the services provided, their rights and obligations, opportunities to manage a fund or withdraw assets from investment accounts, which can become a problem for management in case of low financial literacy of the beneficiary. Accordingly, pricing of services will require taking these circumstances into account, will be associated with risks, and will require new services provided by managers [3].

$\Lambda$ $\mathrm{n}$ important issue in the formation of the trust management services market is the legislative regulation of its functioning. In modern society, only individual regulations are formed, taking into account the specifics of not only the financial market, in general, but trust management or asset storage services (custodians), in particular. For example, in Europe, such tasks are defined within the framework of the European Market for Infrastructure Regulation (EMIR), Retail and Investment Products (PRIP), Financial Directive (MiFID II and III) [1].

Besides, legislation is being formed on trustees and their functions as a special form of banking activity, which includes the Directive on Managers of Alternative Investment Funds (AIFMD), Collective Investment 
Management (UCITS) V, VI and VII, EMIR, PRIPS, MiFID II and III, AIFMD and UCITS V, VI and VII, Shadow Banking I and II, and in the United States legislation on the issue includes the Dodd-Frank amendments to the Investment Advisers Act [1]. In general, the legislation is increasing the requirements for trustees or custodians of assets, especially as for the formation of contracts for the provision of services, product characteristics and risk management. The reformatting of the market leads to increased control and the formation of a separate sector regulating new or relatively new services, and trust management services as well. It is expected that regulation process will only intensify, which may cause the necessity to increase the number of employees in order to ensure that the laws and regulations be executed.

$\mathrm{T}$ The global financial crisis, increased turbulence, complication of the market structure, fight against offshores - all this affects the development of the trust management market, forming both its general characteristics and the trust management market, itself. Against the backdrop of a global financial crisis, confidence in banking services is weakening (and no less services, provided under the management of individual managers), and in Eastern Europe it is also strengthened by relatively high lending rates, which reduce the availability of financial assets and their value. On the one hand, this increases the managers' attention to traditional instruments, but on the other hand, there is a gradual decrease in their profitability in view of new investment instruments.

Lending (primary and refinancing), trading in the secondary market, trading in debt obligations or securities are all added to the management tools. The development of regulatory acts for Asian countries that are developing dynamically is especially relevant. The development of standard regulatory acts for various jurisdictions is becoming an urgent problem for the market development. It is also necessary to develop such regulatory acts that would take into account the necessity to create a Single Data Center.

In parallel with this, it is necessary to develop an insurance market for this type of banking services, which will increase the level of trust in banks, in general and in trustees, in particular, as well as both individual and institutional investors. This is especially true for institutional investors who report on their activities (for example, pension funds are accountable to the state). The creation of reinsurance is possible according to the European Solvency II; however, it requires the development of similar instruments in the countries of Asia and America [1].

In addition, fight against global offshorization, tax evasion and the formation of a global tax as a separate instrument of the financial market serves as limitation for the development of the trust management market. For example, restrictions are introduced as part of the campaign against erosion of the tax base and profits (BEPS), which encompass all financial assets, including those under trust, thus requiring the development of regulation in various jurisdictions to avoid double taxation (DDT). The first examples of such regulation were developed back in 2013 in the Netherlands [1].

$\mathrm{T}$ This gives companies an opportunity, first of all, to increase the profitability of their activities, and, accordingly, increase the benefits of trustees. In fact, there is a consolidation of key jurisdictions in which trustees operate using a global strategy. In accordance with this, in 2010-2015. the provisions of FATCA (Foreign Account Tax Compliance Act) were developed, under which companies (including banks) were to provide information on foreign accounts, the movement of assets in these accounts, the possibility of using offshore zones or reducing tax bases. It should be noted that today there are two key FATCA models in operation, and within their framework reporting and the formation of a global base for the exchange of tax data are being implemented. However, nowadays problems exist with identifying customers and beneficiaries, since as a result of AML (Anti-Money Laundering) system and KYC (Know Your Customer or Know Your Client), which require identification of counterparties before carrying out financial transactions, the structure of beneficiaries becomes more complicated. Such norms exist for all financial institutions (banks, stock exchanges, financial offices, investment funds, mutual funds of various organizational structures) in order to understand the clientele and financial transactions, reduce the risks of financial transactions, and form a transparent tax base [18]. At the present stage, recognition based on biometric and voice identifiers is becoming KYC tools. In addition, customer identification occurs as a result of CDD (Customer Due Diligence), EDD (Enhanced Due Diligence), KYCC (Know Your Customer's Customer).

The main regulatory framework is developed within the FATF (The Financial Action Task Force), which deals with combating the laundering of assets and financial resources, while creating lists of transparent and offshore jurisdictions. At the interstate level, such activities are carried out within the framework of the activities of the IMF.

The practice of implementing global regulatory support as a whole is being adapted to the realities of each individual country. For example, in Russia, these requirements are implemented within the framework of the Federal Law "On Counteracting the Legalization (Laundering) of Criminally Obtained Incomes and the Financing of Terrorism" (No 115-FZ) and the "Regulation on the identification of customers, customer representatives, beneficiaries and beneficial owners by credit institutions in order to counteract the legalization (laundering) of proceeds from crime and the financing of terrorism" (N 499-P).

In the United States of America, the Patriot Act ("The Act "On the Cohesion and Strengthening of Ame- 
rica by Providing the Appropriate Means Needed to Suppress and Determine Terrorism") operates, under which the state can exercise supervision over the financial assets of its citizens.

The UK implements The Money Laundering Regulations, according to which financial companies are accountable to the Joint Money Laundering Steering Group [18].

It should be noted that nowadays, the activities of trustees are complicated by the emergence of cryptocurrencies as a tool in the trust management system, actualizing such issues as settlement of cryptocurrencies and transactions with them.

$\checkmark \mathrm{n}$ n general, KYC and AML requirements are confirmed at the stage of obtaining a license for financial activities or certain types of it. As part of this, AML Bitcoin (Anti-Money Laundering Bitcoin) appears, which was developed taking into account the requirements of financial legislation of both the FATF and the United States, and also the NAC Foundation, whixh is a member of the ABA (American Interbank Association). This currency is completely open to banks or financial institutions, and the owners of the currency are fully authenticated by biometrics, which fact facilitates operations with currency or assets by the trustee [18].

Information about the taxation database greatly complicates the work of trustees; however, this requirement of modern legislation requires managers to provide information on tax evasion at both the state and regional levels. In addition, this legislation causes not only tax evasion, but even assistance in tax evasion (which becomes a functional activity of the trustees themselves). However, in the context of harmonization of individual tax systems, determination of the tax residence of beneficiaries and owners of assets or investors, differences in the approaches to tax the income of investors or owners of capital, certain financial transactions, capital gains in each jurisdiction, the structure and, accordingly, taxation in each jurisdiction complicate the activities of trustees managers [1].

All this requires the formation of global legislation or a database that can be used to obtain information about the owners of assets. However, on the other hand, this can limit the rights of investors or beneficiaries of capital and, besides, requires huge technical capability from banks or foundations to ensure the availability of such a body of data.

In general, in view of the increasing attractiveness of trust management, it is worth noting that all these issues need to be addressed, since there is a gradual redistribution of assets from national platforms to regional and global ones, which requires consolidation of jurisdictions, transformation of commission and pricing models, and increase in the number of passive investments and ETF variability [4].

\section{CONCLUSIONS}

The research conducted shows that most of the problems connected with the development of the trust management market at the present stage of development of the global market, in general, and financial market, in particular, are caused by key trends in the development of markets and, accordingly, the emergence of new players, dictating new rules and introducing new practices. This, in turn, requires identifying the key areas in solving problems, or minimizing the negative consequences of asymmetries in market development.

\section{LITERATURE}

1. Asset Management 2020. A Brave New World. URL: https://www.pwc.com/gx/en/asset-management/ publications/pdfs/pwc-asset-management-2020-abrave-new-world-final.pdf

2. Capitalising on the rise and interconnectivity of the emerging markets. URL: https://www.pwc.com/gx/en/ industries/financial-services/projectblue/rise-of-theemerging-markets-saaame/territory-cuts.html

3. Custody in 2025. Game Changers. Future Trends in Securities Services. URL: https://www.gbm.hsbc.com/ game-changers-future-trends-in-securities-services/ custody-in-2025

4. Hazus. Hazarduous Substance Response Trust Fund / Hearing, public, Heat Islands 101, 1946. P. 57-58.

5. Асаул А. Н., Абаев Х. С., Молчанов Ю. А. Управление, эксплуатация и развитие имущественных комплексов. СПб. : Гуманистика. 2007. 250 с.

6. Бабаева Д. Р. Зарубежный опыт и российская практика трастовых операций коммерческих банков. Региональные проблемы преобразования экономики. 2015. № 9. С. 111-116.

7. Будылгин С. Трасты для чайников: что означают формулировки трастового соглашения? 2014. URL: https://zakon.ru/blog/2014/2/19/trasty dlya_chajnikov_chto_oznachayut_formulirovki_ trastovogo_soglasheniya

8. Воротилов А. Тонкость управления. URL: https:// forbes.kz/finances/markets/tonkost_upravleniya/

9. Генкин А. С. Эффективный траст: опыт Западной Европы и российская практика : учебное пособие. М. : Альпина, 1999. 220 с.

10. Дозорцев В. А. Доверительное управление имуществом (гл. 53) // Гражданский кодекс Российской Федерации. Ч. 2. Текст, комментарии, алфавитно-предметный указатель / под ред. О. М. Козырь, А. Л. Маковского, С. А. Хохлова. М., 1996.

11. Ковалевич А. Е. Доверительное управление: сущность и содержание. Вестник Белорусского государственного экономического университета. 2012. № 4. C. 73-79. URL: http://edoc.bseu.by:8080/bits stream/edoc/1769/2/Kovalevich\%20A.\%20Doveritelnoe\%20upravlenie\%20Vestnik\%20BGEU\%204_12.pdf

12. Мазаева А. В. Доверительное управление и траст: опыт стран континентального права. Журнал зарубежного законодательства и сравнительного правоведения. 2017. № 1. С. 108-113.

DOI: $10.12737 / 24305$ 
13. Мороз М. И. Преимущества и недостатки отдельд ных видов трастов. Вестник Нижегородского университету им. Н. И. Лобачевского. 2016. № 6. C. 156-161. URL: http://www.unn.ru/pages/e-library/ vestnik/19931778_2016_-_6_unicode/24.pdf

14. Риполь-Сарагоси Ф. Б., Терникова Е. В. Доверив тельное управление - прогрессивная форма менеджмента. Инженерный вестник Дона. 2012. № 1. C. 448-451. URL: https://cyberleninka.ru/article/n/ doveritelnoe-upravlenie-progressivnaya-formamenedzhmenta/viewer

15. Смирнов И. Доверительное управление. URL: https://myfin.by/wiki/term/doveritelnoe-upravlenie

16. Федулова Д. В. Гражданско-правовая сущность доь верительного управления. Вестник Томского государственного университета. 2010. № 1. С. 113-116. URL: http://sun.tsu.ru/mminfo/000063105/332/image/332-113.pdf

17. Цвайгерт К., Кётц Х. Введение в сравнительное правоведение в сфере частного права : в 2 т. / пер. с нем. М. : Международные отношения, 2000. Т. 1. 480 с.

18. Минчичова (Павлова) В. Что такое KYC и AML и как это регулируется в России. URL: https://rb.ru/story/ what-is-kyc-and-aml/

Scientific Supervisor - Djakona V. M., Dr. sc. admin., As. Professor, Vice-Rector of ISMA University of Applied Sciences, Latvia, Riga.

\section{REFERENCES}

"Asset Management 2020. A Brave New World". https:// www.pwc.com/gx/en/asset-management/publications/pdfs/pwc-asset-management-2020-a-bravenew-world-final.pdf

Asaul, A. N., Abayev, Kh. S., and Molchanov, Yu. A. Upravleniye, ekspluatatsiya $i$ razvitiye imushchestvennykh kompleksov [Management, Operation and Development of Property Complexes]. St. Petersburg: Gumanistika, 2007.

Babayeva, D. R. "Zarubezhnyy opyt i rossiyskaya praktika trastovykh operatsiy kommercheskikh bankov" [The Foreign Experience and Russian and Russian Practice of Trust Transaction of Commercial Banks]. Regionalnyye problemy preobrazovaniya ekonomiki, no. 9 (2015): 111-116.

Budylgin, S. "Trasty dlya chaynikov: chto oznachayut formulirovki trastovogo soglasheniya?" [Trusts for Dummies: What the Trust Deed Wordings Mean?]. 2014. https://zakon.ru/blog/2014/2/19/trasty_dlya_chajnikov_chto_oznachayut_formulirovki_trastovogo_ soglasheniya

"Capitalising on the rise and interconnectivity of the emerging markets". https://www.pwc.com/gx/en/ industries/financial-services/projectblue/rise-of-theemerging-markets-saaame/territory-cuts.html

"Custody in 2025. Game Changers. Future Trends in Securities Services". https://www.gbm.hsbc.com/game- changers-future-trends-in-securities-services/custody-in-2025

Dozortsev, V. A. "Doveritelnoye upravleniye imushchestvom (gl. 53)" [Trust Management of Property (Chapter 53)].In:Grazhdanskiykodeks RossiyskoyFederatsii.Part 2. Tekst, kommentarii, alfavitno-predmetnyy ukazatel. Moscow, 1996.

Fedulova, D. V. "Grazhdansko-pravovaya sushchnost doveritelnogo upravleniya" [The Civil Legal Essence of Trust Management]. Vestnik Tomskogo gosudarstvennogo universiteta, no. 1 (2010): 113-116. http://sun.tsu. $\mathrm{ru} / \mathrm{mminfo} / 000063105 / 332 / \mathrm{image} / 332-113 . \mathrm{pdf}$

Genkin, A. S. Effektivnyy trast: opyt Zapadnoy Yevropy i rossiyskaya praktika [Effective Trust: Experience of Western Europe and Russian Practice]. Moscow: Alpina, 1999.

"Hazus. Hazarduous Substance Response Trust Fund". Hearing, public, 57-58. Heat Islands 101, 1946.

Kovalevich, A. Ye. "Doveritelnoye upravleniye: sushchnost i soderzhaniye" [Trust Management: Essence and Content]. Vestnik Belorusskogo gosudarstvennogo ekonomicheskogo universiteta, no. 4 (2012): 73-79. http://edoc. bseu.by:8080/bitstream/edoc/1769/2/Kovalevich\%20 A.\%20Doveritelnoe\%20upravlenie\%20Vestnik\%20 BGEU\%204_12.pdf

Mazayeva, A. V. "Doveritelnoye upravleniye i trast: opyt stran kontinentalnogo prava" [Beneficial Ownership and Trust: Experience of Civil Law Countries]. Zhurnal zarubezhnogo zakonodatelstva i sravnitelnogo pravovedeniya, no. 1 (2017): 108-113. DOI: 10.12737/24305

Minchichova (Pavlova), V. "Chto takoye KYC i AML i kak eto reguliruyetsya v Rossii" [What Is KYC and AML and How Is It Regulated in Russia]. https://rb.ru/story/ what-is-kyc-and-aml/

Moroz, M. I. "Preimushchestva i nedostatki otdelnykh vidov trastov" [Advantages and Disadvantages of Certain Types of Trusts]. Vestnik Nizhegorodskogo universitetu im. N. I. Lobachevskogo, no. 6 (2016): 156-161. http://www.unn.ru/pages/e-library/vestnik/19931778_2016_-_6_unicode/24.pdf

Ripol-Saragosi, F. B., and Ternikova, Ye. V. "Doveritelnoye upravleniye - progressivnaya forma menedzhmenta" [Trust Management is a Progressive Form of Management]. Inzhenernyy vestnik Dona, no. 1 (2012): 448-451. https://cyberleninka.ru/article/n/doveritelnoe-upravlenie-progressivnaya-forma-menedzhmenta/viewer

Smirnov, I. "Doveritelnoye upravleniye" [Trust Management]. https://myfin.by/wiki/term/doveritelnoe-upravlenie

Tsvaygert, K., and Ketts, Kh. Vvedeniye v sravnitelnoye pravovedeniye $v$ sfere chastnogo prava [An Introduction to Comparative Law in Private Law], vol. 1. Moscow: Mezhdunarodnyye otnosheniya, 2000.

Vorotilov, A. "Tonkost upravleniya" [Subtlety of Control]. https://forbes.kz/finances/markets/tonkost_upravleniya/ 